\title{
GONDOLATOK A SZOCIALISTA TELEPHELYELMÉLET MEGFOGALMAZÁSÁHOZ
}

\author{
(Thoughts for the Definition of the Socialist Location Theory)
}

\section{BARTA GYÖRGYI}

Bizonyára többen felteszik a kérdést, miért foglalkozunk manapság egy letủnt korszak elemzésével, amikor a jelen problémái előtt is tanácstalanul állunk, nem beszélve a jỏvỏ bizonytalan kilátásairól?

- Indokolhatjuk témaválasztásunkat azzal az érvvel, hogy a szocialista korszak térbeli folyamatainak jobbára csak részleges, empirikus megközelítésen alapuló elemzéseit ismerjük jelenleg. E vizsgálatok eredményei is meglehetősen ellentmondóak, nem ritkán a kutatók politikai elkötelezettségét követve hol a szocialista korszak térbeli kiegyenlítódési folyamatait bizonygatják, hol éppen a térbeli differenciálódás felerősödéséról írnak.

Kétségtelen viszont, hogy a szocialista gazdaság térbeli elrendezỏdésének átalakulását, a térbeli munkamegosztás változásait nem sikerült ez idáig elméleti úton megmagyarázni.

- Érvelhetünk úgy is, hogy jelenlegi problémáink jelentős része szocialista örökségünkkel kapcsolatos. A szocialista rendszer törvényszerüségeinek ismerete nélkül nem érthetjük meg, hogy miért lett válságtérség az észak-magyarországi régióból, amely a szocialista korszak legiparosodottabb térségének számított, miért vált viharos gyorsasággal elmaradott térséggé az alfóldi régió, ahol oly „sikeres” iparfejlesztés zajlott az 1960as, 70-es években, és miért Budapesten és a Dunántúl északi részén lehet csak felmutatni a dinamikus fejlödés jeleit?

Ez a két érv természetesen nem zárja ki, sőt inkább kiegészíti, erősíti egymást.

Ez a tanulmány abból az ötletből született, amely ötvözi Kornai János szocialista rendszert leíró elméletét egy új telephelyelmélettel. Kornai elméletének azokat az elemeit választottam ki és rendeztem logikai egységbe, amelyeknek közvetlen és közvetett kihatása volt a gazdaság (ipar) térbeli elhelyezkedésére. A logikai lánc végül is egy hipotézis megfogalmazásához vezetett, amely szerint:

- a szocialista rendszer mechanizmusai ellentétes irányú területi folyamatokat generáltak;

- azaz részben hatottak a gazdaság térbeli kiegyenlítődésére, míg más folyamatok a területi differenciálódást erỏsitették;

- a meghatározó területi folyamat, véleményem szerint, a térstruktúrák megmerevítéséhez, változatlanságához, vagy rendkívül lassú módosulásához vezetett. (Tehát nem vonom kétségbe a korábbi, egymásnak sokszor ellentmondó empirikus vizsgálatok eredményeit, csupán azt állítom, hogy ezek a területi folyamatok egy-egy elemét ragadták csak meg). 
A hipotézis bizonyítása még elöttem álló feladat. Ez a tanulmány - talán még a hipotézis bizonyítása nélkül is - képes vitát provokálni, és akkor már elérte célját.

\section{A szocialista telephelyelmélet hiánya}

Az elmúlt 40 év során a területi kérdésekkel foglalkozó magyar szakemberek nem mutattak különösebb érdeklődést az elméleti kérdések iránt, és így érthetö, hogy a szocialista telephelyelmélet megfogalmazására sem tettek erőfeszítéseket. A néhány publikáció egybehangzóan állította, hogy „még adós a szocialista tudomány az alapvető területi („térgazdasági”) törvényszerüségek egyértelmủ és konkrét feltárásával” (Bernát T.-Bora Gy.-Köszegi L. 1968), és így önálló szocialista telephelyelméletek sajnos mind ez ideig még nem alakultak ki (Zoltán Z. 1980).

Vajon mi a magyarázata annak, hogy nem sikerült feltárni a szocialista rendszer és a telephelyválasztás gyakorlata közötti elméleti kapcsolatokat, vagyis nem sikerült választ találni arra, hogy milyen általános szempontok hatottak az egyes telephelyek kiválasztására, illetve az ipar térbeli megoszlására és annak változására?

Tulajdonképpen Kornai János híres könyvének, A hiánynak a megjelenéséig (1980) nem is meglepö, hogy nem született meg a szocialista telephelyelmélet. Ennek kidolgozásához ugyanis arra lett volna szükség, hogy ismert legyen a szocialista rendszer általános múködési mechanizmusa, az uralkodó tulajdon- és hatalmi viszonyok rendszere és az ennek hatására kialakuló döntéshozási mechanizmus. Ugyancsak Kornai János müvéböl vált nyilvánvalóvá és egyértelmủvé a mikro- és makroszféra szocializmusbeli összefüggése, vagyis a vállalatok és az állam szocialista jellegú viszonya.

Kornai elméletéböl kitủnik, hogy a szocialista rendszer a kapitalista rendszertől alapvetően eltérỏ logika alapján müködött, azt is mondhatnánk, hogy a szocialista rendszer sok szempontból a tőkés rendszer ellentéte, vagy inverze volt.

Ebből az is következik, hogy minden esetben, amikor a szocialista sajátosságok megmagyarázásának kiindulópontja a tőkés telephelyelmélet volt, a magyarázat téves vágányra csúszott.

A másik megoldatlan kérdés vagy tévedés a mikro- és makrorendszer viszonyának magyarázatával függött össze. Voltak olyan nézetek, amelyek egyszerúen nem vették tekintetbe, hogy a szocialista vállalatok alapvetóen másféle szervezetek, mint a tőkés vállalatok. A klasszikus szocialista vállalat a paternalista vállalat, amelynek célja nem a profit növelése volt, hanem a piachelyettesítő állam által meghatározott szükségletkielégítés (Kopányi M. 1988). A szocialista vállalatok tehát jogilag nem voltak önálló szervezetek, sokkal inkább kívülról vezérelt termelőegységek. És bár kialakultak a szocialista vállalat elkülönült érdekei is, melyeket - különösen a gazdasági reform bevezetése után - a magyar vállalat egyre eróteljesebben érvényesíthetett az állammal kötött alkuiban - az államtól való fùggése mindvégig rendkívül erós maradt, önálló mozgástere lényegesen 
szükebb és bizonytalanabb volt, mint a tơkés vállalaté. Ez elsősorban a vállalat tevékenységével, céljaival kapcsolatos korlátozott döntéshozás mechanizmusában nyilvánult meg.

A másik téves megközelítés abból fakadt, hogy a mikroszférát jórészt vagy teljes egészében negligálták, és nemcsak egyszerủen a makroszintủ meghatározottságot hangsúlyozták. A korábbi gazdasági irányitási rendszerben például eléggé általánosan érvényesült az a személet, amely az egész szocialista gazdaságot (ipart) egyetlen vállalatként fogta fel, az alsóbb (vállalati) szervek önállóságát minimálisra szorította le és formálissá tette (Bernát T.-Bora Gy.-Köszegi L. 1968). Míg tehát a tökés telephelyelmélet eredetileg és alapjaiban mikroökonómiai jellegü, amelyhez később kapcsolódott néhány makroökonómiai szempont is, addig a szocialista telephelyelmélet eredetére nézve és alapjaiban, makroökonómiai jellegủ, amelyhez értelemszerüen késöbb kapcsolódott a vállalati szintủ mérlegelés néhány tényezöje is (Illés I. 1983).

A különböző megközelítések legnagyobb hiányossága azonban az a tisztázatlanság volt, hogy hogyan kapcsolódott a mikro- és a makroszféra egymáshoz, amelynek rövid leírására - Kornai elméletére alapozva - a későbbiekben térünk ki. Azt azonban leszögezhetjük, hogy a telephely sajátosan olyan kategória, amelynek vizsgálata során legfeljebb a mikro- vagy a makroszint meghatározó szerepéröl beszélhetünk, de egyik megközelítési aspektus sem hagyható figyelmen kívül.

Végül még egy magyarázó ok arra, hogy miért nem rendelkezünk szocialista telephelyelmélettel. A szocialista politikai-társadalmi-gazdasági jelenségek leírásakor gyakori és közel sem volt véletlenszerủ az a mód, ahogy a megtörtént eseményeket, a realitásokat összekeverték a vágyakkal, tervekkel és célokkal oly módon, mintha ez utóbbiak már megvalósultak volna. Nyilvánvaló, hogy az elmélet, amely egy jelenségcsoport összefúggéseinek és szabályosságainak általános leírása, s okainak magyarázata (Kornai J. 1980), csak a valóban létező jelenségekkel foglalkozhat. Így mindazok, akik a szocializmus távlati programjaihoz (gazdasági körzetek kialakitása, a termelőerők területi elhelyezési tervei, a területi-termelési komplexumok elképzelései stb.) kötötték vélt szocialista telephelyelméleteiket, irreális, nem valós szférában gondolkoztak. Ezek az „elméletek” semmilyen bizonyítást nem nyertek, semmilyen próbát nem álltak ki, valójában nem is tekinthetök elméleteknek.

\section{Kísérlet a szocialista telephelyelmélet megfogalmazására}

A telephelyelmélet a vállalatok (telephelyek) letelepítésének, illetve a telephelyek (vállalatok) közötti munkamegosztás törvényszerüségeivel foglalkozik. A telephelyi struktúrában akkor következik be változás, ha vállalatokat alapítanak, megszüntetnek, fejlesztenek vagy visszafejlesztenek, ha vállalatokat összevonnak, vagy részekre bontanak. Az említett állapotváltozások a beruházás folyamatához kapcsolódnak. Ebból következik, hogy a szocialista telephelyelmélet megfogalmazásához a beruházáshoz felhasználható erőforrásokat, a beruházó intézményeket és személyiségeket kell számba vennünk, illẹtve a beruházás szocialista módon szabályozott mechanizmusát kell nyomon követnünk. 
A szocialista rendszer: eröforrás korlátos gazdaság

Kornai egy táblázatba sürítette össze a „,klasszikus” kapitalista és az ugyancsak „,klasszikus” szocialista vállalat tiszta típusainak alapvetỏ különbségeit:

\begin{tabular}{|c|c|c|}
\hline Korlátozó feltétel & $\begin{array}{c}\text { Klasszikus kapitalista } \\
\text { vállalat }\end{array}$ & $\begin{array}{c}\text { Hagyományos szocialista } \\
\text { vállalat }\end{array}$ \\
\hline Eröforráskorlát & Ritkán effektív & $\begin{array}{l}\text { Majdnem mindig effektív, } \\
\text { szúkebb a keresleti korlátok- } \\
\text { nál }\end{array}$ \\
\hline Keresleti korlátoknál & $\begin{array}{l}\text { Majdnem mindig effektív, } \\
\text { szükebb a erőforráskorlátnál }\end{array}$ & Ritkán effektív \\
\hline Költségvetési korlát & Kemény & Puha \\
\hline \multirow[t]{2}{*}{ Termelési terv } & $\begin{array}{l}\text { Autonóm: a vállalat maga } \\
\text { szabja meg }\end{array}$ & Utasítás: A felsó szerv írja elö \\
\hline & $\begin{array}{l}\text { A keresleti korlát szintjén van, } \\
\text { az erơforráskorlátnál szükebb }\end{array}$ & $\begin{array}{l}\mathrm{Az} \text { erőforráskorlát szintjén } \\
\text { van, a keresleti korlátnál szü- } \\
\text { kebb }\end{array}$ \\
\hline
\end{tabular}

Forrás: Kornai J.: A hiány. 43. o. (KJK, Budapest, 1980)

Végeredményben e különbségekben lehet megtalálni azt a kiindulópontot is, amelyre a szocialista telephelyelmélet építhető: ez a szocialista vállalat, amelynek nem autonóm tervét egy felső szerv határozta meg, és utasította annak végrehajtására.

Mivel a beruházás és a vállalati jövedelmezóség között alapjában véve nem volt összefüggés (amely adatokkal is igazolható: Kornai J.-Matits Á. 1989), a vállalatok számára a beruházás sohasem jelentett kockázatot. Ezt nevezi Kornai puha költségvetési korlátnak. (Vagyis a vállalat költségvetési hiányát az állam igyekezett pótolni). Ez azt eredményezte, hogy a vállalatok ,beruházási éhsége" sohasem csillapult, szünt meg. Így a beruházások határa, korlátja az erőforrások elérhetó, szétosztható mennyisége volt. Az állandó hiány az eröforrásokban a szocialista rendszer kísérö jelenségévé vált.

Tehát a szocialista vállalat telepitését, telephelyválasztását nem a profit-maximalizálás célja határozta meg, hanem az erőforrások elérhetösége.

Talán egy fontos kérdés nincs belefoglalva a táblázatba: az egész rendszert hajtó, mozgató belső nỏvekedési kényszer, amelynek különböző motivációi vannak (a gazdaság egészének szintjén a gazdasági lemaradás csökkentése, az utolérési effektus; vállalati szinten a hiány, illetve a hiány okozta sokszor szinte értelmetlen készletgyüjtés, a tervteljesítési kötelezettség és a vezetók készséges azonosulása a felettes szerv elvárásaival, illetve a vezetői hatalom növekedése a vállalat növekedésével). Errỏl természetesen Kornai másutt tesz említést.

A szocialista telephelyválasztás tehát az eróforrások elérhetőségétỏl: az erőforrások természetétől (minőségétỏl és mennyiségétöl, szerkezeti összetételétől), illetve az erőfor- 
rások elosztásának rendszerétól (a döntéshozás rendszerétöl, a döntéshozók preferenciáitól és az erőforrásokat igénylö vállalatok alkupozícióitól) függött.

\section{Az eröforrások típusai}

Az erőforrásokat ebben az esetben csak egy szempont - térbeli mobilitásuk szerint tipizáljuk. E szerint megkülönböztetünk mobil és immobil eröforrásokat. Azt feltételezzük, hogy az immobil erőforrások kényszert jelentenek a beruházó, a telepítő számára, mivel azok csak ott helyben érhetök el, használhatók fel. A telepítéshez szükséges többi erőforrás a mobil eröforrás, melyek a beruházó dőntése alapján követik az immobil erőforrásokat, vagyis azok helye, települése felé vonzódnak.

Az eróforrásokat három csoportba osztottuk:

- Környezeti eröforrások: ebbe a csoportba tartoznak mindazok az eróforrások, amelyek majdnem vagy teljesen helyhez kötöttek, térbelileg nem mobilizálhatók (a természeti erőforrások, a beépített környezet, vagyis a kiépitett infrastruktúra, a településhálózat, a földrajzi adottságok, az externáliák és az immobil tőke).

- A munkaerõ: gyakorlatilag részben mobilizálható tényező. A mobilizálhatóság nagymértékben függ a munkát keresók és a felkínált munkahelyek számának arányától. Abban az időszakban, amikor a munkaerö-bőség, illetve a munkaerö felesleg a jellemzö, a munkaerö rákényszerül arra, hogy kövesse az elérhető munkahelyeket. Munkahely túlkínálat, illetve munkaerőhiány idején a munkaerő válogathat a munkahelyekben, és számára nyilván kedvezőbb lakóhelyéhez közelebb esó munkahelyet választani, ahonnan nehezen mozdul el.

A munkát keresőknek egy nem elhanyagolható része semmilyen körülmények között nem mobilizálható (a családhoz, gyerekneveléshez, a háztáji gazdasághoz kötött nök, akik az ingázást is csak korlátozottan vállalják, a lakásváltás rendkivüli akadályai miatt nehezen mozduló emberek stb.), de helyben hajlandó munkát vállalni.

A szocialista periódusban a felesleges munkaerő felszívása hosszabb idón keresztül ment végbe. Az elsó időszakban a nehézipari nagyberuházások régiók közötti vándorlási hullámokat generáltak. A munkaerö utánpótlás elégtelenségét először Budapesten lehetett észlelni már a 1960-as évek közepén, majd a nagyvárosok is munkaeró-gondokkal kezdtek küszködni. Végül a munkaeröt keresỏ vállalatok már arra kényszerultek, hogy a nem mobilizálható munkaerơ számára helyben létesítsenek ipari üzemeket, részlegeket.

A szocializmus utolsó szakaszában a munkaerő vált az ipartelepítés döntỏ tényezőjévé, a telephely kiválasztásában alapvető szerepe lett.

- A tôke: térbeli szempontból mobil tényező, amelynek térbeli elhelyezési változatai különösen a szocialista intenzív redisztribúciós rendszerben - szinte korlátlanok voltak.

A telephely kiválasztását az immobil eröforrások elérhetősége, jelenléte határozza meg, a szocializmus elsö időszakában föként a környezeti tényezö, késöbb egyre inkább a munkaeröforrás térsége, helye lett a meghatározó, a kulcsfontosságú faktor. A már mü- 
ködö vállalat állóeszköz állományának (immobil töke) szinten tartása (amortizáció) a beruházások igen jelentős részét emésztette fel.

Miután feltételeztük, hogy mely eröforrások találhatók helyben és melyek vihetők el a helyhez.kötött erőforrások településébe, az a kérdés, hogy miként osztották szét a tőkét a letelepülni szándékozó, telephelyet kereső, illetve a már letelepült és fejlődni kívánó vállalatok között, mely vállalatokat részesítették elönyben, melyeket hanyagoltak el?

\section{A tỏke újraelosztásának gyakorlata}

A több évtizedes gyakorlat egyértelmủen bebizonyította, hogy a vállalatok jövedelmezösége nem vagy alig játszott szerepet a beruházási erőforrások elérhetőségében. Mi határozta meg tehát azt, hogy a tőke-allokátor miként osztotta szét a tökét (állami támogatást vagy hitelt) az igénylő vállalatok között?

Kornai három szabályosságot, módszert ír le:

- Hüvelykujj-szabálynak nevezi az elosztásnak azt a rendjét, amely szerint minden igénylő ugyanakkora részt kapott, mint a korábbiakban. Azt is mondhatjuk, hogy bizonyos status quo alakult ki az ágazatok, szervezetek, térségek, fejlesztési célkitűzések stb. között, amelyre az igénylő az újabb és újabb igényeit építette, és amely az allokátor számára mindvégig vonatkoztatási alap maradt.

- Az ủn. tủzoltórendszer akkor lépett életbe, amikor valamilyen területen a hiány túlzottan felduzzadt, amikor a korábbi arányokạt módosítani kellett a hazai termelés vagy export dilemmája, a feszítỏ munkaerőhiány, új technológiák alkalmazása, vagy egyéb hirtelen probléma fellépése (katasztrófa, válság stb.) miatt.

- Az egész elosztási procedúrában, ahol mindig a hiánnyal, a kielégítetlen igények okozta feszültségekkel kellett küzdeni, jelen volt a beruházások elhalasztására való törekvés. Ez átmeneti idö- és tőkenyereséget jelentett az elosztó szerv számára. Az elhalasztott beruházásokból eredỏ hiányok viszont decentralizáltan jelentkeztek, amelyeknek gyengébb volt a visszhangja, szétszórtan mutatkozott a visszahatása.

Ezek után az a kérdés maradt megválaszolatlanul, hogy melyek voltak az elosztás korábban kialakult arányai, pontosabban milyen preferenciák voltak jellemzỏek a szocialista gazdaságban?

\section{A szocialista gazdaság preferenciái}

A szocialista gazdaság megkülönböztetett céljait, előnyben részesített ágazatait, szervezeteit stb., amelyek az elöbbiekben említett status quo rendszerét alkotják, két csoportba osztottam:

- A politikai preferenciákra, amelyeknek legföbb jellegzetessége az, hogy uralják a gazdasági preferenciákat. Ezek között két fontos szempont vált meghatározóvá: a szocialista gazdaság autarkiája, az önellátásra való törekvése, és a mindent meghatározó 
külpolitika, amely Magyarországot a Szovjetunióhoz (illetve a többi szocialista országhoz) kötötte szorosan, míg a nyugati világhoz füződő kapcsolatai nem váltak, nem válhattak jelentössé.

- A politikai preferenciáknak alárendelt gazdasági preferenciákra, amelyek egyaránt megmutatkoztak:

1) az ágazatok között (a bányászat és a nehézipar kiemelt fejlesztése a hadiipar fejlesztésével, illetve az önellátásra való törekvéssel összefüggésben);

2) a szervezetek között (Kornai sorrendet állított fel a gazdasági szervezetek között az állami preferenciákhoz való viszonyuk alapján. E szerint: nagy állami vállalatok, állami kis- és középvállalatok, mezőgazdasági termelöszövetkezetek, nem mezőgazdasági termelöszövetkezetek, a hivatalos magán szektor, a nem hivatalos magán szektor (Kornai J. 1989). Az állami gazdaságpolitika tehát az állami nagyvállalatokat részesítette elỏnyben (amelyeknek részletes leirását adja Szalai E. 1982, 1988, 1990, 1991; Voszka É. 1988);

3) a gazdasági célkitũzések között (az iparfejlesztés kapott elsőbbséget a gazdaság többi ágazata rovására; az ország lassú gazdasági nyitása Nyugat felé pedig a növekvő importot fedező exportorientációt tette szükségessé.)

\section{A gazdasági reform kihatásai}

A gazdasági reform jelentősen módositotta a szocialista gazdasági mechanizmus egyes elemeit, valóságos piaci hatások müködését segítette elö, mindazonáltal alapvetően nem változtatta meg a gazdasági rendszer szocialista jellegét. Így azok az ellentmondások, melyek a korábbiakban a gazdaságot feszitették, némileg visszaszoritva, módosítva továbbra is fennálltak. Jellemzỏ maradt a beruházási éhség, a hiány, a vállalatok puha költségvetési korlátja, a jövedelmezőség és a beruházások laza kapcsolata. Végeredményben a megreformált gazdaság fejlödését, növekedését továbbra is az erőforrások elérhetősége korlátozta.

Mindemellett a telephelyválasztás, ipartelepítés gyakorlata fontos pontokon módosult a reform különbözö intézkedéseinek tulajdoníthatóan:

- A reform bevezetése elött igen jelentős vállalati összevonásokat hajtottak végre. Az 1960-as évek elején ennek hatására mintegy egyharmadával csökkent az iparvállalatok száma. Ezeknek az intézkedéseknek elsősorban az volt a célja, hogy a bürokratikus vezetés számára megkönnyitse az irányitást és áttekinthetővé tegye a gazdaság pillanatnyi helyzetét. Komoly aggodalmak merültek fel ugyanis abban a vonatkozásban, hogy a vállalatok önállóvá válásával a politikai vezetés elvesziti a kontrollt a gazdaság felett. Különböző megelöző intézkedéseket hoztak ekkor, például bevezették az átlagbérszabályozás rendszerét. Ezek közé az intézkedések közé tartozott a vállalati összevonások kezdeményezése és végrehajtása is. Az aggodalmak ugyan többnyire feleslegesnek bizonyultak, az óriásvállalatok azonban ekkor jelentek meg a gazdaságban és ekkor indult el az a fo- 
lyamat, amely a nagyvállalatokat meghatározó politikai-gazdasági hatalmi tényezóvé emelte.

- A reform egyik fö célja a vállalati önállóság megteremtése volt. Ez gyakorlatilag azt jelentette, hogy a vállalatok önállóan rendelkezhettek megtermelt nyereségük egy részével. Bár az erőteljes támogatási-elvonási rendszer következtében a jövedelmezöbb vállalatok nem válhattak ki, nem fejlődhettek gyorsabban az átlagosaknál, és noha a veszteséges vállalatok az állami támogatásnak köszönhetően továbbra is életben maradhattak, ettől az időtől kezdve az ipari beruházások 30-40\%-a a vállalatok saját beruházása volt.

Részben a gazdasági reform következményeként a gazdaság extenzív fejlödése felgyorsult az 1960-as, 1970-es években. A felgyorsult növekedés felerösitette az eröforrások hiányából adódó feszültségeket.

A fent emlitett három tényezỏ alapvetően megváltoztatta a nagyvállalatok helyzetét - a kiemelt állami támogatásnak és az önállóságuknak köszönhetően lényegesen gyorsabban növekedtek, fejlödtek, mint a kis- és középvállalatok. A helyi munkaerö miatt kezdetben vidéken hoztak létre telephelyeket, majd a vidéki munkaeröhiány kiapadásával - a bürokratikus vezetés támogatására támaszkodva - tömegesen olvasztották be a kisvállalatokat, a szövetkezeteket és más vállalatok részlegeit.

Ez a folyamat vezetett a részleg-ipar széles körü elterjedéséhez, különösen az ország kevésbé fejlett régióiban és az ipari térségek környezetében. Az ipari termelés addig soha nem látott mértékben szóródott szét az országban. A termelés dekoncentrációjával párhuzamosan viszont, a nagyvállalatok beolvasztási törekvéseinek tulajdoníthatóan, az irányítás centralizálódását lehetett nyomon követni. (Barta Gy. 1990, 1991)

\section{Az ipartelepítést befolyásoló tényezők együttes hatása az ipar térbeli struktúrájának formálásában}

Végigkísértük azokat a folyamatokat, amelyek alakították, illetve befolyásolták az ipartelepítés folyamatát. E folyamatok egyes tényezői egymást erösítő, vagy éppen egymás ellen ható térbeli folyamatokat generáltak. Újra végighaladva az elöbbiekben leírt folyamatokon, vegyük most sorra, hogy az ipartelepítéshez kapcsolódó tényezök különkülön, miként befolyásolták az ipar térbeli elhelyezkedését:

\section{Az erőforrások térbeli elérhetősége}

A környezeti erőforrás immobil tényezöjének elérése és megszerzése azt eredményezi, hogy az ipari telephely választása során a már kialakult térbeli struktúrát veszik számításba, pontosabban azok közül a települések közül választanak telephelyet a letelepítendö vagy fejlesztendỏ ipar számára, amelyekben a környezeti erőforrások már rendelkezésre 
állnak. Ez nyilvánvalóan a kialakult ipari térstruktúra arányainak megőrzését, megerősítését hozta magával.

Még az ipar eröteljes térbeli szétszóródása idején is, amikor a kisebb településekben, falvakban tömegesen nyitottak ipari telephelyeket, megfigyelhetô volt, hogy a telephelyet létesítő anyaüzemek figyelmet fordítottak arra, miként takarékoskodhatnak a termelöi infrastrukturális beruházásokkal. Jobbára olyan településeket választottak, amelyekben találtak még szabad infrastrukturális kapacitásokat. (A szük keresztmetszetet föként a víz és az energia jelentette ekkor. Szívesen vették, ha a település ingyen ajánlott fel telket, épuletet és egyéb eszközöket az ipari üzem számára). „Zöldmezős” beruházásokra csak kivételesen került sor, és ritka volt az olyan „ipari park” jellegü beruházás is, amely éppen az infrastruktúra elözetes kiépítésével és a szolgáltatások kínálatával vonzotta a telephelyet kereső iparvállalatokat.

A munkaerö elérhetősége volt az egyik legfontosabb faktor az ipar térbeli struktúrájának formálásában. A szocialista iparosítás kezdetén, amikor munkaerö-felesleg volt országszerte, a területileg koncentrált ipartelepítés tömeges népvándorlást indított el. Ebben az idöszakban a környezet faktor helyhez kötött térstruktúrája szabta meg az ipari munkaerő térbeli megoszlását is - ez pedig, mint jeleztük, a korábbi térstruktúrát követte.

A munkaeröforrás kiapadásával azonban a munkaerö vált az igazán ,szük keresztmetszetté", a telepítést, telephelyválasztást meghatározó tényezövé. Az egyre immobilabbá váló munkaerő-tényező rákényszerítette az iparirányító szerveket, később az ipartelepítésben alapvetö szerepet játszó iparvállalatokat, hogy kövessék a kis, helyi munkaeröpiacokat, és akár nagy vagy közepes méretü falvakban is nyissanak üzemeket. (A falusi iparosítás során például a 4000 fös település bizonyult még elfogadható méretünek egyegy kisebb üzem letelepitésére. Persze ezt a „népesség kuszöböt" nagymértékben befolyásolták a települési viszonyok, a közlekedési adottságok és a helyi gazdaság körülményei). Mindenesetre az immobil munkaerő megszerzése járult hozzá a részleg-ipar országos méretủvé válásához, az ipari termelés addig soha nem látott térbeli dekoncentrációjához. Ez a faktor tehát a fó tényezöje volt az ipari térstruktúra megváltozásának, az új ipari térstruktúra kialakulásának.

A tőke mint erőforrás faktor térbeli szempontból (elméletileg) teljesen mobil. A töke elosztásának módja határozta meg tehát, hogy a tỏke szétosztása a korábbi térstruktúrát erősítette-e, vagy új térfolyamatokat indított-e el.

\section{A töke szétosztása}

Kövessük Kornai három szabályát a tőke szétosztásában. A ,hüvelykujj” módszer, amely a korábban kialakult arányokat és irányokat tekinti mérvadónak és kiindulási pontnak, nyilvánvalóan a tóke területek közötti megoszlását, megosztását is meghatározta. Ez volt az a szabály, amely a legeröteljesebben hatott a korábbi ipari térstruktúra megőrzésére, megerösítésére. (Ez közvetlenül megnyilvánult a már múködö eszközállomány 
amortizációjában, amely a beruházások igen jelentős hányadát tette ki. De ezt igazolják Kornai János és Matits Ágnes (1989) számításai is, amelyek szerint a jövedelemelvonás és támogatás átfogó rendszerének segítségével olyan kiegyenlítődés jött létre a nyereséges és a veszteséggel müködő vállalatok között, amely nem engedte, hogy a jól múködö vállalatok kiemelkedjenek, a veszteséges vállalatok tönkremenjenek).

A tőke elosztás, ,hüvelykujj”” szabálya merevítette meg, őrizte meg a vállalatok, illetve a vállalatok térségeinek kialakult struktúráját.

A tủzoltás módszerének bevetése nem volt ritka ugyan, de alkalomszerü beavatkozást jelentett. Ez a módszer inkább a korábbi térstruktúra megőrzésére hatott, mint annak megváltoztatására.

A beruházások elhalasztása jobbára minden területet sújtott. Ennek térbeli differenciáló kihatásait, mintegy ellenpontként, a szocialista preferenciák számbavételével vizsgálhatjuk.

\section{A szocialista gazdaság preferenciái}

Az iparágazatok közötti preferenciák, amelyek a bányászatnak, a nehéziparnak, illetve a hadiiparnak kedveztek, kétféle területi folyamatot erősítettek. A helyhez kötött erőforrások felhasználása - elsősorban a természeti kincsek fokozott kiaknázása - a korábbi térstruktúra fennmaradását segítette elö. A nagyarányú nehézipari beruházások azonban módosítottak is a korábbi ipari térstruktúrán, azt eredményezve, hogy a fejlett és fejletlen területek között növekedtek a különbségek.

A szervezetek közötti preferenciák az állami nagyvállalatoknak kedveztek. A nagyvállalati székhelyek területi koncentrációja, föként Budapesten és az ország nagyvárosaiban, egyben szintén a fejlett ipari területek javára történő elmozdulást ösztönözték.

A szocialista gazdaság kitüntetett célja - az iparfejlesztés és az exportösztönzés ugyancsak a fejlett térségekben múködő nagyvállalatoknak nyújtottak előnyöket.

Összefoglalva tehát az a véleményem, hogy a szocialista gazdaság preferenciái a tökeberuházásokat fóként az iparilag fejlett területek felé irányították elősegítve ezzel a térbeli különbségek növekedését.

\section{A gazdasági reform hatása az ipar térbeli struktúrájára}

A gazdasági reform kettős, térbelileg egymással szemben ható folyamatot erősített fel: a termelés térbeli dekoncentrációját és a szervezeti irányitás területi centralizációját. Az előbbi tehát az új ipari térstruktúra kialakulására, a térbeli különbségek csőkkenésére hatott, mig a szervezeti centralizáció a területi polarizálódást, a fejlett térségek felgyorsuló fejlödését segítette elő.

Nem kétséges, hogy a részleg ipar vidéki szétterülése nem egyenlíthette ki a vállalati székhelyek együtteséböl formálódó centrum települések gazdasági előnyeit. A részleg- 
ipari jellegủ fejlődés az elmaradott térségekben ellentmondásos folyamat volt, amely nem vezetett a térség megalapozott ipari fejlődéséhez sőt, mint a külföldi és a magyar példák egyaránt bizonyítják, a részlegipar a gazdasági válság elsö számú áldozatává válik. (Érdemes nyomon követni, miként vonult ki a budapesti nagyvállalati székhelyủ ipar a vidék gazdaságából!)

\section{A területi folyamatok összessége}

Az iparfejlesztés tehát háromféle egymással szemben ható területi folyamatot generált, a korábbi térbeli arányok megörzését, a különbségek növelését a fejlett és fejletlen területek között, illetve az új ipari térstruktúra kialakulását föként a korábban elmaradott ipari területek dinamikus fejlődésével. A kérdés az, hogy az egyenleg megvonása után melyik folyamat tekinthetỏ meghatározó, domináns folyamatnak, kiegyenlítve a kevésbé jelentős ellentétes hatásokat is?

Hipotézisem szerint - számba véve az egyes faktorok jelentőségét és gyakoriságát - a meghatározó erő a korábbi ipari térstruktúra fenntartását segítette eló. Kevésbé jelentősek azok az erök, amelyek a szocialista érában a térbeli különbségek kiegyenlítésére hatottak. $\mathrm{Az}$ új ipari térstruktúra kialakulására ható erök befolyásolták legkevésbé az ipari térstruktúra formálódását.

Igen szerencsések vagyunk, hogy ezeket a feltételezéseket módunkban áll adatokkal igazolni, vagy megcáfolni.

\section{Irodalom}

Bernát T.-Bora Gy.-Kőszegi L. (1968) Termelöerôk területi elhelyezése. MKKE. Tankönyvkiadó, Budapest. Illés I. (1983) Regionális gazdaságıan. ELTE Természettudományi Kar. Tankönyvkiadó, Budapest. Kopányi M. (1988) A vállalat. In: Mikroökonómia. (Szerk.: Kopányi M.) MKKE, Budapest, 60-151 . o. Kornai J.-Matits Á. (1989) A vállalati nyereség bürokratikus újraelosztása. In: Régi és új ellentmondások és dilemmák. (Szerk.: Kornai J.) Gyorsuló Idó. Magvetó, Budapest, 92-174. o.

Kornai J. ( I980) A hiány. Kozgazdasági és Jogi Könyvkiadó, Budapest.

Szalai E. (1982) A reformfolyamat és a nagyvállalatok. Valóság, 5. 23-25. o.

Szalai E. (1988) Reformtörekvések és nagyvállalati érdekek a nyolcvanas években. Valóság, 11. 14-33. o.

Szalai E. (1990) Gazdaság és hatalom. Aula Kiadó, Budapest.

Szalai E. (1991) A hatalom metamorfózisa? Valóság, 6. 1-26. o.

Voszka É. (1988) Reform és átszervezés a molcvanas években. Idôszerü Közgazdasági Kérdések. Kozgazdasági és Jogi Konnyvkiadó, Budapest.

Zoltán Z. (szerk.) (1980) Telephelyválasztás. Kozgazdasági és Jogi Konyvkiadó, Budapest. 


\title{
THOUGHTS FOR THE DEFINITION OF THE SOCIALIST LOCATION THEORY
}

\author{
GYÖRGYI BARTA
}

What could be the explanation for the failure of exploring the theoretical connections between the socialist system and the practice of the choice of location so far? Why have we proved unsuccessful so far in exploring what general aspects have affected the choice of certain locations, the spatial distribution of the industry and the transition of that?

It is not surprising that before the publication of János Kornai's famous book called $A$ hiány (The Absence, 1980) there had not been a socialist location theory, since the elaboration of that requires competence on the general function mechanism of the socialist system, the system of the power and property relationships and the decision mechanism that is formed as a consequence of this. It is János Kornai's work again that made the connection of the micro- and macro-spheres in the socialism, i. e. the socialist type relationship between the companies and the state evident.

This study attempts to build up the socialist location theory from some elements of János Kornai's theory describing the socialist system. As a consequence of this a hypothesis was stated which says that the mechanisms of the socialist system generated regional processes of opposite direction. Among these the dominant regional process led to the conservation, or at least the extremely slow transition of the spatial structures.

A great part of our present problems can be connected to our socialist legacy. Without being familiar with the regularities of the socialist system we cannot understand why the northern Hungarian region that had been the most industrialised area of the socialist era became a crisis region, why the Great Plain region where so "successful" industrial development had taken place in the 1960s and 1970s turned to an underdeveloped region at an extremely rapid pace, and why the signs of dynamic development can only be seen in Budapest and the northern part of Transdanubia. 